\title{
Study New Pyridine Derivatives as Corrosion Inhibitors for Mild Steel in an Acidic Media
}

\author{
Rania Kareem Hameed* and Mehdi Salih Shihab \\ Department of Chemistry, College of Science, Al-Nahrain University, Baghdad, Iraq
}

\begin{tabular}{|c|c|}
\hline Article's Information & Abstract \\
\hline $\begin{array}{l}\text { Received: } \\
\text { 18.05.2021 } \\
\text { Accepted: } \\
\text { 07.06.2021 } \\
\text { Published: } \\
\text { 30.09.2021 }\end{array}$ & $\begin{array}{l}\text { Some new pyridinium salts, namely } 4 \text {-(4-bromo-benzylidene-hydrazinocarbonyl)- } \\
\text { 1-phenyl-pyridinium bromide, } \mathrm{A} 1 ; 4 \text {-(4-bromo-benzylidene-hydrazinocarbonyl)-1- } \\
\text { butyl-pyridinium bromide, A2; } 4 \text {-(4-bromo-benzylidene-hydrazinocarbonyl)-1- } \\
\text { phencyl-pyridinium bromide, } \mathrm{A} 3 ; \text { were synthesized and studied as corrosion } \\
\text { inhibitors for mild steel in } 1 \mathrm{M} \mathrm{H} \mathrm{H}_{2} \mathrm{SO}_{4} \text { aqueous solution at } 20^{\circ} \mathrm{C} \text { by weight loss } \\
\text { measuring for } 24 \mathrm{hrs} \text {. The results showed that the inhibition efficiency of all } \\
\text { pyridinium bromide derivatives had a significant in value with the highest }\end{array}$ \\
\hline $\begin{array}{l}\text { Keywords: } \\
\text { Pyridinium salts } \\
\text { Corrosion } \\
\text { Mild steel } \\
\text { Adsorption isotherm }\end{array}$ & $\begin{array}{l}\text { concentration. An increase in the inhibitor concentration is accompanied by a } \\
\text { decrease in the corrosion rate, an increase in the retarding efficiency and an } \\
\text { increase in the degree of surface coverage. The values of the free energy of } \\
\text { adsorption revealed the effects of spontaneously reaction of (A1, A2, and A3) and } \\
\text { gave useful information to predict the interaction between the metal surface and } \\
\text { the organic molecules as corrosion inhibitors. }\end{array}$ \\
\hline
\end{tabular}

DOI: $10.22401 /$ ANJS.24.3.01

*Corresponding author: raniakareem925@gmail.com

\section{Introduction}

Corrosion is the degradation of a material's basic properties as a result of chemical reactions with its environment. Per year, erosion costs millions of dollars. Corrosion of iron and steel accounts for a significant portion of this loss, though certain other metals, such as [1], can also corrode Hydrochloric and sulfuric acids are commonly used in the metallurgical industry in a variety of techniques such as pickling minerals to extract scale. Mineral corrosion can be attributed to two factors: water and oxygen. When these two factors interact with the metal in just the right way, corrosion can be accelerated. Furthermore, metal corrosion is accelerated by chloride ions and an acidic environment. Since anodic and cathodic reactions occur simultaneously on the surface of corroded metal, it is referred to as a mixed electrode. The hybrid electrode is a single metal surface that contains an entire electrochemical cell. As a result, iron corrosion is the most common and critical electrochemical reaction. [2]. Inhibitors are substances or mixtures that resist, prevent, or minimize corrosion when used in a highaggressive environment [3]. The organic compounds used as inhibitors may function as cathodic, anodic, or combined inhibitors, as well as cathodic and anodic inhibitors, but they usually operate through a surface adsorption mechanism that results in the formation of a film. Naturally, the presence of molecules with a high affinity for metalsurface compounds indicates high inhibition efficiency and low risk to the environment $[4,5]$. In general, the inhibitor mechanism is one or more of the three described below: the inhibitor is chemically adsorbed (chemical absorption) on the metal surface and forms a protective film with the effect of inhibitor, or the inhibitor contributes to the formation of a film by the oxide defense by combining the inhibitor ions with the metal surface [6]. The retarder interacts with a potent substance as it comes into contact with the base metal. These retarders form absorbent water-proof molecules on the metal's surface, preventing the metal from dissolving into the electrolyte. In the medium surrounding the metal, it must be soluble or dispersible [7]. Metal corrosion, which affects the metallurgical, chemical, and petroleum industries, is still a global science problem. The growing interest in producing acidic beverages. The need to learn more about the corrosion resistance of mild steel to acidic media has been fueled by the media [8]. Pickling, washing, and descaling are only a few of the industries that use acids. Retarders are used to slow the rate of mineral dissolution due to their violent nature. Nitrogen, sulfur, and oxygen-containing compounds have been identified as potent inhibitors [9-11]. With $\mathrm{N}, \mathrm{O}, \mathrm{S}$, and $\mathrm{P}$ atoms, the metal ion functions as an electrophilic and organic compound, with single pairs of nucleophilic centers readily available for sharing. In acidic media, some organic derivatives have also been studied as corrosion inhibitors for various metals and alloys [12-16]. In the current work, by preparing Schiff base compounds and reacting $\mathrm{N}$ alkylation with alkyl halides, we can obtain pyridinium bromide salts. Weight loss measurements were used to investigate corrosion and corrosion inhibition of mild steels 


\section{Al-Nahrain Journal of Science}

ANJS, Vol.24 (3), September, 2021, pp. 1-8

in $1 \mathrm{M} \quad \mathrm{H}_{2} \mathrm{SO}_{4}$ solution without and with prepared pyridinium salt (A1, A2, and A3) for 24 hours at $20^{\circ} \mathrm{C}$.

\section{Experimental}

\subsection{Materials}

All of the chemicals (reagents and solvents) were used without further purification.

\subsection{Instrumentation}

The compounds' infrared spectra were re-encoded as potassium bromide $(\mathrm{KBr})$ tablets in the wave number range (4000-400) $\mathrm{cm}^{-1}$ and ${ }^{1} \mathrm{H}-\mathrm{NMR}$ (DMSO-d) using SHIMADZU's FTIR 8300. The hot-phase Gallenkamp melting point apparatus was used to measure melting points using the open capillary process, and the results were incorrect. The composition of mild steel samples was determined using SPECTROMAXx (2009, Germany) (General Company for Inspection and Rehabilitation, Ministry of Industry and Materials, Baghdad).

\section{Synthesis of pyridinium bromide derivatives}

Pyridinium bromide derivatives inhibitors, namely: namely3-(4-Bromo-benzylidene-hydrazinocarbonyl)-1- phenyl-pyridinium bromide, A1; 3-(4-Bromo-benzylidenehydrazinocarbonyl)-1-butyl-pyridinium bromide, A2; 3-(4Bromo-benzylidene-hydrazinocarbonyl)-1-phencylpyridinium bromide, A3; were synthesized as follow: - Preparation compound of Schiff base [17]. The Schiff base compound was obtained by reacting equal amounts $(0.01 \mathrm{~mol})$ of isonicotinic acid hydrazide and $\mathrm{p}$ bromobenzaldehyde in $25 \mathrm{~mL}$ of ethanol with the addition of a few drops of glacial acetic acid for 8 hrs. The Schiff base compound was precipitated after cooling, then filtered and purified by recrystallization from ethanol.

- Preparation of pyridinium bromide derivatives (A1-A3) [18]. The pyridinium bromide derivatives were prepared by reaction a mixture of $(0.01 \mathrm{~mol})$ of the prepared Schiff base compound and $(0.01 \mathrm{~mol})$ of (benzyl bromide, butyl bromide or phenacyl bromide $)$ in $(2 \mathrm{ml})$ of absolute ethanol to remain overnight at room temperature in a round bottom flask. The mixture was then refluxed for 25 hrs. The resulting solution was evaporated and the solid was washed with 3 parts $(10 \mathrm{ml})$ diethyl ether. The molecular formula of the proposed inhibitors are shown Figure 1.

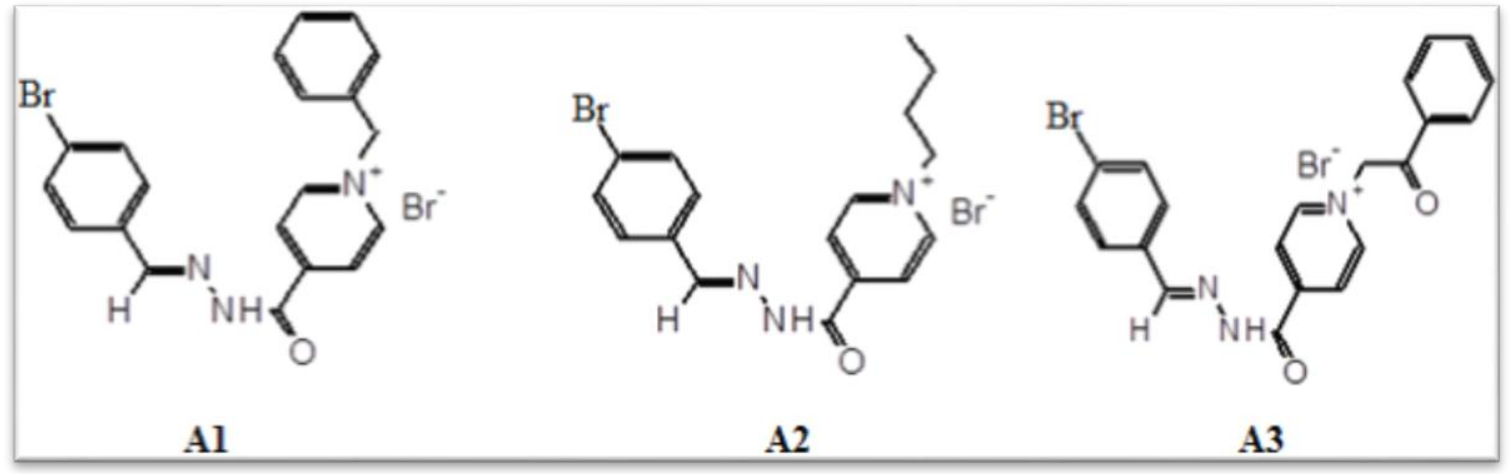

Figure 1. The molecular formula of the proposed inhibitors (A1, A2 and A3).

\subsection{Making an aggressive approach}

Dilution of analytical grade 98 percent $\mathrm{H}_{2} \mathrm{SO}_{4}$ with distilled water yielded an aggressive solution of $1 \mathrm{M} \mathrm{H}_{2} \mathrm{SO}_{4}$. At 20 ${ }^{\circ} \mathrm{C}$, inhibitor concentrations range $\left(1 \times 10^{-2}\right.$ to $\left.5 \times 10^{-4} \mathrm{M}\right)$ were prepared in a $1 \mathrm{M} \mathrm{H}_{2} \mathrm{SO}_{4}$ solution.

\subsection{Weight loss measurements}

A sheet of mild steel used had composition ratios $(0.002 \%$ P, $0.288 \% \mathrm{Mn}, 0.03 \% \mathrm{C}, 0.0154 \% \mathrm{~S}, 0.0199 \% \mathrm{Cr}, 0.002 \%$ $\mathrm{Mo}, 0.065 \% \mathrm{Cu}, 0.0005 \% \mathrm{~V})$ and the rest was made of iron. Mild steel sheets were mechanically cut into a disk form with a diameter of $2.5 \mathrm{~cm}$. To achieve a smooth surface, these disc shapes are sanded with sandpaper. Then they used distilled water, alcohol, and acetone to disinfect. After being cleaned, the samples were placed in a dehumidifier before being used in corrosion tests. Mild steel samples were first measured in an electrostatic balance. Then, the samples were suspended and completely immersed in a $250 \mathrm{~mL}$ beaker containing $1 \mathrm{M}$ sulfuric acid in the presence and absence of inhibitors for $24 \mathrm{~h}$. After 24 hours of exposure at $20{ }^{\circ} \mathrm{C}$, samples were removed, washed with water to eliminate any corrosive products, and then washed with acetone. They were then weighed after drying for 24 hours in a dryer. The mass loss measurements were carried out using the ASTM method [19,20], which has already been identified The tests were done twice to ensure that the results were reliable and that an average weight loss value could be recorded. Weight loss made it possible to calculate the average wear rate in $\left(\mathrm{mg} \mathrm{cm}^{-2}\right.$ hours $\left.^{-1}\right)$. Relationship was used to calculate the corrosion rate of mild steel (1) [21]:

$$
W=\frac{\Delta m}{S \times t}
$$

where $m$ loss is the area $\left(\mathrm{cm}^{2}\right)$ and the immersion period (hours). The damping efficiency ratio $(E \%)$ was calculated using relationship (2) [22]: 


\section{Al-Nahrain Journal of Science}

ANJS, Vol.24 (3), September, 2021, pp. 1-8

$$
E \%=\frac{W \operatorname{corr}-W \operatorname{corr}(\text { inh })}{W \operatorname{corr}} \times 100 \% .
$$
where Wcorr and Wcorr (inh) are the corrosion rates of mild steel in the absence and presence of inhibitor, respectively.

\section{Results and Discussion}

Scheme 1 shows the preparation of pyridinium bromide derivatives (A1-A3) of the present work.

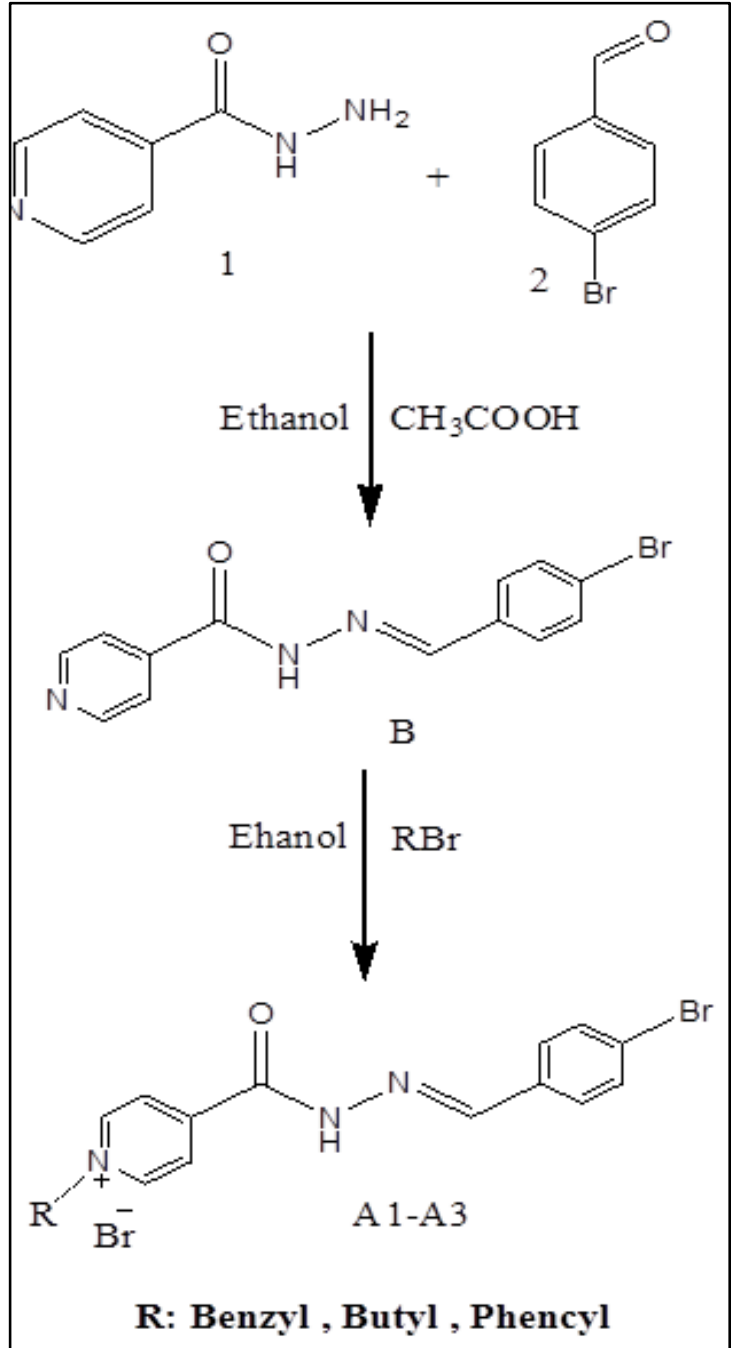

Scheme 1. Synthesis steps of the pyridinium salts (A1, A2, and A3).

The above reactions were included in the preparation of pyridinium bromide derivatives (A1, A2 and A3) using ionicotinic acid hydrazide to perform a Schiff reaction with p-bromobenzaldehyde. Then the reaction followed by the substitution reaction with alkyl bromide. Table 1 summarizes the FT-IR spectral data and physical properties of the prepared compounds, while Table 2 lists the $1 \mathrm{H}-$ NMR spectral data in parts per million for the compounds (A1-A3) (2). 


\section{Al-Nahrain Journal of Science}

ANJS, Vol.24 (3), September, 2021, pp. 1-8

\begin{tabular}{|c|c|c|c|c|c|c|}
\hline $\begin{array}{l}\text { Comp. } \\
\text { No. }\end{array}$ & Chemical formula & M.W. (g/mol) & Color & M.P. ${ }^{\circ} \mathrm{C}$ & $\begin{array}{c}\text { Yield } \\
\%\end{array}$ & $\begin{array}{c}\text { FT-IR } \\
\left(\mathrm{cm}^{-1}, \text { stretching }\right)\end{array}$ \\
\hline 1 & Isonicotinichydrazide & $\mathrm{C}_{6} \mathrm{H}_{7} \mathrm{~N}_{3} \mathrm{O}$ & White & 173 & - & $\begin{array}{c}\text { Amine }(\mathrm{N}-\mathrm{H}) 3300 \text { and } 3173 \\
\text { Aromatic }(\mathrm{C}-\mathrm{H}) 3049 \text { aliphatic }(\mathrm{C}-\mathrm{H}) \\
2860 \\
\text { Amide }(\mathrm{C}=\mathrm{O}) 1668 \\
\end{array}$ \\
\hline 2 & P-bromobenzaldehde & $\mathrm{C}_{7} \mathrm{H}_{5} \mathrm{BrO}$ & White & 57 & - & $\begin{array}{l}\text { Aromatic }(\mathrm{C}-\mathrm{H}) 3086 \\
\text { Aliphatic }(\mathrm{C}-\mathrm{H}) 2856 \\
\text { Aldehyde }(\mathrm{C}=\mathrm{O}) 1687\end{array}$ \\
\hline B & $\begin{array}{c}\text { Isonicotinic acid (4- } \\
\text { bromo-benzylidene)- } \\
\text { hydrazide }\end{array}$ & $\mathrm{C}_{13} \mathrm{H}_{10} \mathrm{BrN}_{3} \mathrm{O}$ & White & 76 & 72 & $\begin{array}{c}\text { Aromatic }(\mathrm{C}-\mathrm{H}) 3029 \\
\text { Aliphatic }(\mathrm{C}-\mathrm{H}) 2943 \\
\text { Azomethine }(\mathrm{C}=\mathrm{N}) 1631\end{array}$ \\
\hline A1 & $\begin{array}{c}\text { 3-(4-bromo- } \\
\text { benzylidene- } \\
\text { hydrazinocarbonyl)- } \\
\text { 1-phenyl-pyridinium } \\
\text { bromide } \\
\end{array}$ & $\mathrm{C}_{19} \mathrm{H}_{15} \mathrm{BrN}_{4} \mathrm{O}_{3}$ & Brown & Gummy & 75 & $\begin{array}{c}\text { aromatic }(\mathrm{C}-\mathrm{H}) 3033 \text {, aliphatic }(\mathrm{C}-\mathrm{H}) \\
\text { 2971, amide }(\mathrm{C}=\mathrm{O}) 1646, \\
\text { amide }(\mathrm{N}-\mathrm{H}) 3361, \\
\text { imine }(\mathrm{N}=\mathrm{C}) 1682\end{array}$ \\
\hline A2 & $\begin{array}{c}\text { 3-(4-bromo- } \\
\text { benzylidene- } \\
\text { hydrazinocarbonyl)- } \\
\text { 1-butyl-pyridinium } \\
\text { bromide }\end{array}$ & $\mathrm{C}_{20} \mathrm{H}_{18} \mathrm{BrN}_{3} \mathrm{O}$ & Brown & Gummy & 76 & $\begin{array}{c}\text { aromatic }(\mathrm{C}-\mathrm{H}) 3146, \text { aliphatic }(\mathrm{C}-\mathrm{H}) \\
\text { 2960, amide }(\mathrm{C}=\mathrm{O}) 1640, \\
\text { amide }(\mathrm{N}-\mathrm{H}) 3340, \\
\text { imine }(\mathrm{N}=\mathrm{C}) 1669\end{array}$ \\
\hline A3 & $\begin{array}{c}\text { 3-(4-bromo- } \\
\text { benzylidene- } \\
\text { hydrazinocarbonyl)- } \\
\text { 1-phenacyl- } \\
\text { pyridinium bromide }\end{array}$ & $\mathrm{C}_{19} \mathrm{H}_{16} \mathrm{BrN}_{3} \mathrm{O}$ & Yellow & Gummy & 85 & $\begin{array}{c}\text { aromatic }(\mathrm{C}-\mathrm{H}) 3046, \text { aliphatic }(\mathrm{C}-\mathrm{H}) \\
\text { 2960, amide }(\mathrm{C}=\mathrm{O}) 1640, \\
\text { amide }(\mathrm{N}-\mathrm{H}) 3308, \\
\text { imine }(\mathrm{N}=\mathrm{C}) 1670\end{array}$ \\
\hline
\end{tabular}

Table 2. The ${ }^{1} \mathrm{H}-\mathrm{NMR}$ spectral data of compounds (C1-C3) in ppm.

\begin{tabular}{|c|c|c|}
\hline Comp. No. & Compound structure & 1H-NMR data of $(\delta-H)$ in ppm \\
\hline A1 & & $\begin{array}{l}1 \mathrm{H} \text { of } \mathrm{N}-\mathrm{H}(-\mathrm{CO}-\mathrm{NH}-\text { moiety) }(10.3) ; 4 \mathrm{H} \text { of } \\
\text { pyridine-ring }(9.0-9.4) ; 1 \mathrm{H} \text { of } \mathrm{N}==\mathrm{CH}-(8.5) ; \\
9 \mathrm{H} \text { of phenyl- rings }(7.0-8.2), 2 \mathrm{H} \text { of }-\mathrm{N}^{+}-\mathrm{CH}_{2} \\
\text { group (6.0); }\end{array}$ \\
\hline $\mathbf{A 2}$ & & $\begin{array}{l}1 \mathrm{H} \text { of } \mathrm{N}-\mathrm{H}(-\mathrm{CO}-\mathrm{NH}-\text { moiety) }(11.3) ; 4 \mathrm{H} \text { of } \\
\text { pyridine-ring }(8.8-9.4) ; 1 \mathrm{H} \text { of } \mathrm{N}==\mathrm{CH}-(8.5) \text {; } \\
4 \mathrm{H} \text { of phenyl- rings }(7.2-8.2), 2 \mathrm{H} \text { of }-\mathrm{N}^{+}-\mathrm{CH}_{2} \\
\text { group }(4.6) ; 7 \mathrm{H} \text { of aliphatic chain }(0.8-1.9)\end{array}$ \\
\hline $\mathbf{A 3}$ & & $\begin{array}{l}1 \mathrm{H} \text { of } \mathrm{N}-\mathrm{H}(-\mathrm{CO}-\mathrm{NH}-\text { moiety) }(11.4) ; 4 \mathrm{H} \text { of } \\
\text { pyridine-ring (8.6-9.2); } 1 \mathrm{H} \text { of } \mathrm{N}=\mathrm{CH}-(8.5) \\
9 \mathrm{H} \text { of phenyl- rings (7.2-8.3), } 2 \mathrm{H} \text { of }-\mathrm{N}^{+}-\mathrm{CH}_{2} \\
\text { group (6.6); }\end{array}$ \\
\hline
\end{tabular}




\section{Al-Nahrain Journal of Science}

ANJS, Vol.24 (3), September, 2021, pp. 1-8

The results of the corrosion rate and inhibition efficiency obtained from weight loss measurements at different concentrations of the proposed inhibitors (A1, 12,
13) after 24 hours of immersion at $20{ }^{\circ} \mathrm{C}$ are summarized in Table 3 and are illustrated in Figures 2 and 3.

Table 3. Corrosion rate $\left(W_{\text {corr. }}\right)$, Damping efficiency $(E \%)$, surface coverage $(\theta)$ and standard absorption energy $\left(\mathrm{G}^{\circ}\right.$ ads) for mild steel in $1 \mathrm{M} \mathrm{H}_{2} \mathrm{SO}_{4}$ using weight loss measurements, where time $(T)$ was 24 hours.

\begin{tabular}{|c|c|c|c|c|}
\hline Concentration $(M)$ & Corrosion rate $\left(\mathrm{mg} \cdot \mathrm{cm}^{-2} \cdot \mathrm{h}^{-1}\right)$ & $E \%$ & $\theta$ & $\Delta G^{\circ}$ ads (kJ. mol $\left.{ }^{-1}\right)$ \\
\hline Blank & 0.344 & & & \\
\hline A1 & & & & \\
\hline $5 \times 10^{-4}$ & 0.2441 & 29.04 & 0.2904 & \multirow{4}{*}{$\begin{array}{c}-27.51 \\
\mathrm{R}^{2}=0.9991\end{array}$} \\
\hline $1 \times 10^{-3}$ & 0.1702 & 50.04 & 0.5052 & \\
\hline $5 \times 10^{-3}$ & 0.1286 & 62.61 & 0.6261 & \\
\hline $1 \times 10^{-2}$ & 0.1163 & 66.19 & 0.6619 & \\
\hline \multicolumn{5}{|l|}{$\mathrm{A} 2$} \\
\hline $5 \times 10^{-4}$ & 0.2999 & 12.82 & 0.1282 & \multirow{4}{*}{$\begin{array}{c}-27.68 \\
R^{2}=0.9979\end{array}$} \\
\hline $1 \times 10^{-3}$ & 0.1452 & 57.79 & 0.5779 & \\
\hline $5 \times 10^{-3}$ & 0.0160 & 95.35 & 0.9535 & \\
\hline $1 \times 10^{-2}$ & 0.0140 & 95.93 & 0.9593 & \\
\hline \multicolumn{5}{|l|}{ A3 } \\
\hline $5 \times 10^{-4}$ & 0.0428 & 87.56 & 0.8756 & \multirow{4}{*}{$\begin{array}{c}-33.50 \\
\mathrm{R}^{2}=0.9999\end{array}$} \\
\hline $1 \times 10^{-3}$ & 0.0309 & 91.02 & 0.9102 & \\
\hline $5 \times 10^{-3}$ & 0.0097 & 97.18 & 0.9718 & \\
\hline $1 \times 10^{-2}$ & 0.0094 & 97.27 & 0.9727 & \\
\hline
\end{tabular}

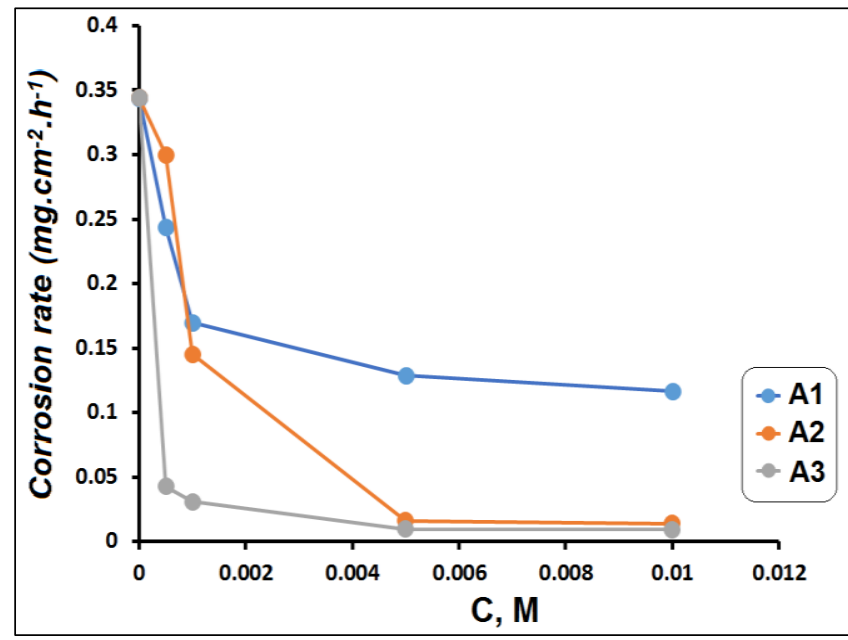

Figure 2. The effect of inhibitor concentrations (A1, A2, and $\mathrm{A} 3$ ) on the rate of corrosion for mild steel in $1 \mathrm{M} \mathrm{H}_{2} \mathrm{SO}_{4}$ at $20^{\circ} \mathrm{C}$.

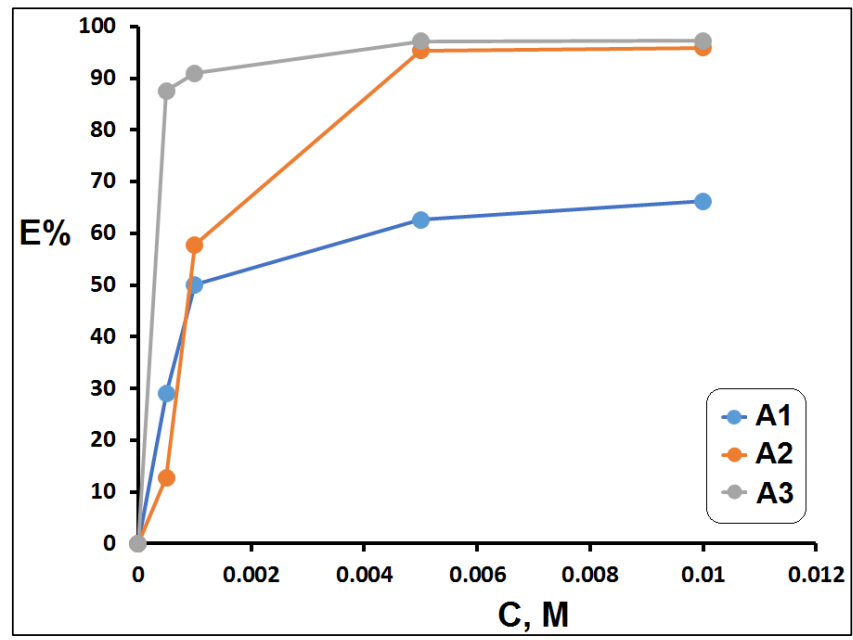

Figure 3. The influence of inhibitor concentrations on the inhibition efficiency of $1 \mathrm{M} \mathrm{H}_{2} \mathrm{SO}_{4}$ soft steel at $20{ }^{\circ} \mathrm{C}$ for the proposed inhibitors (A1, A2, A3). 


\section{Al-Nahrain Journal of Science}

ANJS, Vol.24 (3), September, 2021, pp. 1-8

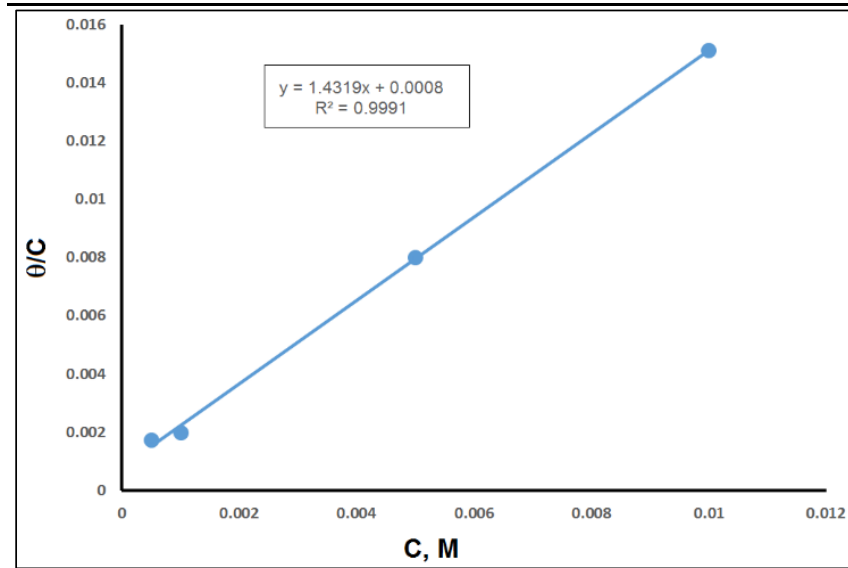

Figure 4. The linear relationship between $C / \theta$ versus $C$ for (A1).

Table 3 shows that as the inhibitor concentration is increased, the defense efficiency improves, with the highest inhibition efficiencies reached at 10-2 M. As a result of the comparison, the inhibition efficiency of (A1, A2, and A3) is roughly equivalent. The effect of organic molecular structure on inhibition efficiency may explain the rapprochement in inhibition efficiency.

Inhibitors affect the efficiency of inhibition as well as the adsorption mechanism. The adsorption isotherms may provide basic details to understand the interaction between organic compounds and metal surfaces. As a result, weight loss measurements (listed in Table 3) were used to determine the degree of surface coverage values $(E \% / 100)$ for different inhibitor concentrations in $1 \mathrm{M} \mathrm{H}_{2} \mathrm{SO}_{4}$ at $20^{\circ} \mathrm{C}$ and tested with Langmuir isotherm relationship (3) [23]:

$$
C / \theta=1 / K_{a d s}+C
$$

where the equilibrium constant of the adsorption phase is $K_{a d s}$, and $\mathrm{C}$ is the concentration in $\mathrm{M}$.

The intercepts of the straight line plotting $C / \theta$ versus $C$ Figure can be used to measure $K_{a d s}$ values according to the Langmuir isotherm (3). With the following equation, Kads is compared to the normal free energy of adsorption, $\Delta G^{o}$ ads: (The value 55.5 is the molar concentration of water in the solution in $\mathrm{M}$ ).

$$
K_{a d s}=\frac{1}{55.5} e^{\left(-\frac{\Delta G_{a d s}}{R T}\right)}
$$

Table 3 shows that the values of the standard free energy of adsorption are negative to indicate that the adsorption processes of all the proposed inhibitors (A1, A2, A3) were spontaneous processes on the surface of mild steel after 24 hours of immersion at $20{ }^{\circ} \mathrm{C}$ and this is to give meaning to the observed interaction between Suggested damper and metal surface. Here, the adsorbent molecule moves near the surface of the metal causing the electrons to begin to interfere with the surface atoms causing the decomposition of the proposed inhibitors [24-27].

It is generally accepted that the adsorption of an organic inhibitor on a metallic surface in an acidic medium usually includes the formation of a metal inhibitor compound by combining the inhibitor with the newly generated $\mathrm{Fe}^{2+}$ ions on the surface of the steel [28]:

$$
\begin{aligned}
& \mathrm{Fe}+2 \mathrm{H}^{+} \longrightarrow \mathrm{Fe}^{2+}+\mathrm{H}_{2} \\
& \mathrm{Fe}+2 \mathrm{H}^{+} \longrightarrow[\mathrm{Fe}-\mathrm{Inh}]^{+2} \text { (ads) (Metal-inhibitor } \\
& \text { complex })
\end{aligned}
$$

As a result, the formation of a metal-inhibitor complex may act as a protective layer for anodic sites, preventing $\mathrm{Fe}^{2+}$ sites from forming. As a result, at low concentrations of suggested inhibitors, the likelihood of forming a compact metal-inhibitor complex is low. Adsorption activity of organic molecules containing $\mathrm{N}, \mathrm{O}$ atoms determines the adsorption mechanism for specific inhibitors. The existence of multiple functional groups has been shown to cause changes in a molecule's electron density, which can affect its adsorption activity [29]. The proposed inhibitors could adsorb with the corroding metal surface through a compact metal-inhibitor complex on anodic sites, reducing the loss of $(\mathrm{Fe})$ atoms from the surface due to electrochemical dissolution. The interaction between the organic molecule and the metal surface is improved by the normal distribution of the electronic density on the surface of the organic molecule.

Finally, Figure 5 depicts the interaction mechanism that predicts the modeling representation of the imine, oxygen atom, and aromatic groups of suggested inhibitor molecules adsorption process on mild steel sutures.

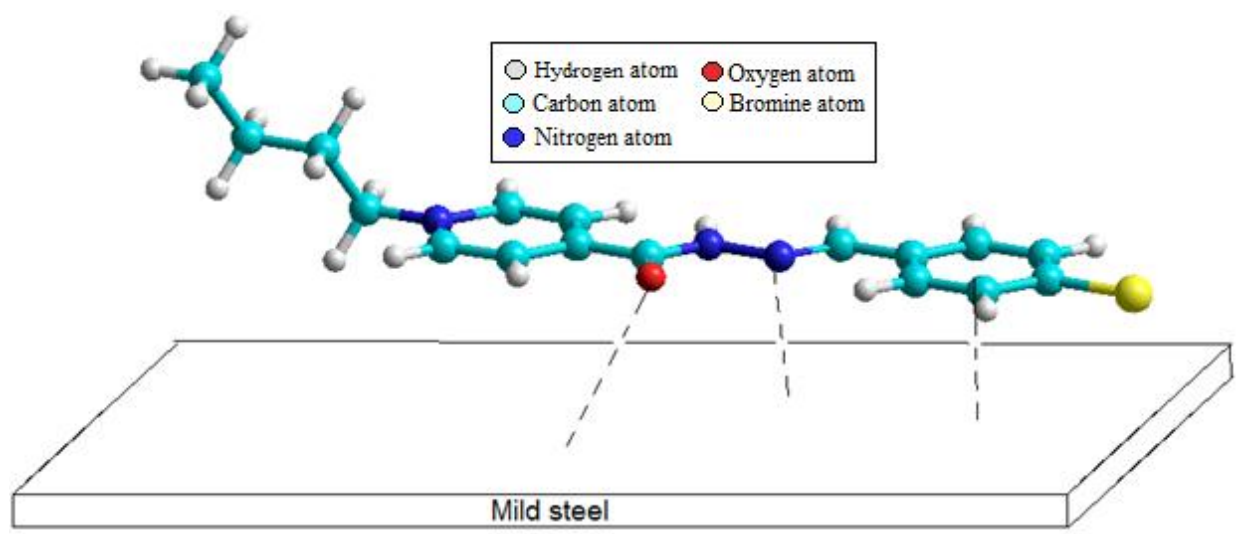

Figure 5. Suggested interaction mechanism for inhibitor molecules on the mild steel surface. 


\section{Al-Nahrain Journal of Science}

ANJS, Vol.24 (3), September, 2021, pp. 1-8

\begin{abstract}
4. Conclusion
In $1 \mathrm{M} \mathrm{H}_{2} \mathrm{SO}_{4}$ aqueous solution at $20^{\circ} \mathrm{C}$, pyridinium-derived composites (A1, A2, and A3) have been successfully used as corrosion inhibitors on the surface of mild steel. The findings of inhibitory efficacy (E percent) revealed that the proposed inhibitors had interesting inhibitory effects. The absorption free energy values (A1, A2, A3) revealed the effect of decomposition of the materials (A1, A2, A3) and provided and provided knowledge that was useful in explaining the interaction between the metal surface and the organic molecules.
\end{abstract}

\section{References}

[1] Revie R. W.; "Corrosion and corrosion control: an introduction to corrosion science and engineering", John Wiley \& Sons, 51, 3848-3854, 2008.

[2] Abdel-Rehim S. S.; Khaled K. F. and Abd-Elshafi N. S.; "Electrochemical frequency modulation as a new technique for monitoring corrosion inhibition of iron in acid media by new thiourea derivative". ElectrochimicaActa, 51(16), 3269-3277, 2006.

[3] Lebrini M.; Roos C.; Vezin H. and Robert F.; "Electrochemical and theoretical studies of adsorption of some indole derivates at C38 steel/sulfuric acid interface as corrosion inhibitors". Int. J. Electrochem. Sci, 6, 3844-385, 2011.

[4] El-Haddad M. N.; "Chitosan as a green inhibitor for copper corrosion in acidic medium". International journal of biological macromolecules, 55, 142-149, 2013.

[5] Loutfy H. M. and Elroby S. K.; "Aminic nitrogenbearing polydentate Schiff base compounds as corrosion inhibitors for iron in acidic and alkaline media: A combined experimental and DFT studies". J. Corros. Sci. Eng., 17, 2014.

[6] Santos F. C.; Albuquerque M. A.; Oliveira M. C. C. and Echevarria A.; "A corrosão e os agentes anticorrosivos". Revista virtual de química, 6(2), 293-309, 2014.

[7] James O.; Oforka N. C. Abiola and O. K.; "Inhibition of acid corrosion of mild steel by pyridoxal and pyridoxol hydrochlorides". International Journal of Electrochemical Science, 2, 278-284, 2007.

[8] Lagrenée M.; Mernari B.; Bouanis M.; Traisnel M. and Bentiss F.; "Study of the mechanism and inhibiting efficiency of 3,5-bis(4-methylthiophenyl)-4H-1,2,4triazole on mild steel corrosion in acidic media". Corrosion Science, 44(3), 573-588, 2002.

[9] Quraishi M. A. and Sardar R.; "Aromatic triazoles as corrosion inhibitors for mild steel in acidic environments". Corrosion, 58(9), 748-755, 2002.

[10] Singh A. K. and Quraishi M. A.; "The effect of some bisthiadiazole derivatives on the corrosion of mild steel in hydrochloric acid". Corrosion Science, 52(4), 1373-1385, 2010.

[11] Shihab M. S. and A. F. Mahmood, "Experimental and theoretical study of some N-pyridinium salt derivatives as corrosion inhibitors for mild-steel in acidic media". Russian Journal of Applied Chemistry, 89(3), 505-516, 2016.

[12] Nazari M. H.; Shihab M. S.; Havens E. A. and Shi X.; "Experimental and theoretical research on the mechanism of corrosion safety in chloride solution by an apple-based green inhibitor 1:7". Journal of Infrastructure Preservation and Resilience, 2010.

[13] Khudhair Z. T. and Shihab M. S.; "Study synergistic effect of some pyrazole derivatives as corrosion inhibitors for mild steel in $1 \mathrm{M} \mathrm{H}_{2} \mathrm{SO}_{4}$ ". Surface Engineering and Applied Electrochemistry, 56(5), 601-609, 2020.

[14] Nazari M. H.; Shihab M. S.; Cao L.; Havens E. A. and Shi X.; "A peony-leaves-derived liquid corrosion inhibitor: protecting carbon steel from $\mathrm{NaCl}$ ". Green Chemistry Letters and Reviews, 10(4), 359-379, 2010.

[15] Shihab M. S. and Mahmood A. F.; "Approach for Synthesis of N-pyridinium Derivatives using Schiff's Base Compounds". KKU Journal of Basic and Applied Sciences, 3(2), 36-38, 2017.

[16] Issa R. M.; Khedr A. M. and Rizk H.; "1H NMR, IR and UV/VIS Spectroscopic Studies of Some Schiff Bases Derived From 2-Aminobenzothiazole and 2Amino-3-hydroxypyridine". Journal of the Chinese Chemical Society, 55, 875-884, 2008.

[17] Daeniker H. U. and Grob C. A.; "3-quinulidone hydrochloride". Organic Syntheses, Coll., 5, 989 (1973).

[18] ASTM G.; "G-Standard practice for laboratory immersion corrosion testing of metals". West Conshohocken, PA; ASTM, 31-72, 1990.

[19] Ajmal M.; Mideen A. S. and Quraishi M. A.; "2hydrazino-6-methyl-benzothiazole as an effective inhibitor for the corrosion of mild steel in acidic solutions". Corros. Sci., 36, 79, 1994.

[20] Scendo M. and Hepel , "Inhibiting properties of benzimidazole films for $\mathrm{Cu}(\mathrm{II}) / \mathrm{Cu}(\mathrm{I})$ reduction in chloride media studied by RDE and EQCN techniques". Journal of Electro Analytical Chemistry. 613(1), 35-50, 2008.

[21] Elachouri M.; Hajji M. S. and Salem M.; "Some nonionic surfactants as inhibitors of the corrosion of iron in acid chloride solutions". Corrosion, 52(2), 103108, 1996.

[22] Agrawal R. and Namboodhiri T. K. G.; "The inhibition of sulphuric acid corrosion of 410 stainless steel by thioureas". Corros. Sci., 30, 37, 1990.

[23] AMaayta. K. and Al-Rawashdeh N. A. F.; "Inhibition of acidic Corrosion of Pure Aluminum by Some Organic Compounds". Corros. Sci., 46, 1129, 2004.

[24] Donahue F. M. and Nobe K.; "Theory of Organic Corrosion Inhibitors: Adsorption and Linear Free Energy Relationships". J. Electrochem. Soc., 112, 886, 1965.

[25] Kamis E.; Bellucci F.; Latanision R. M. and El-Ashry E. S. H.; "Acid Corrosion Inhibition of Nickel by 2 - 


\section{Al-Nahrain Journal of Science}

ANJS, Vol.24 (3), September, 2021, pp. 1-8

\section{(Triphenosphoranylidene) Succinic Anhydride".} Corrosion, 47, 677, 1991.

[26] Bentiss F.; Lebrini M. and Lagrenée M.; "Thermo dynamic characterization of metal dissolution and inhibitor adsorption processes in mild steel /2, 5-bis (n-thienyl)-1, 3, 4-thiadiazoles/hydrochloricacid system". Corros. Sci., 47, 2915-2931, (2005)

[27] Oguzie E. E.; Li. Y. and Wang F. H.; "Corrosion inhibition and adsorption behavior of methionine on mild steel in sulfuric acid and synergistic effect of iodide ion". Journal of Colloid and Interface Science, 310, 90-98, 2007.

[28] Hackerman N. and Cook E. L.; "Effect of Adsorbed Polar Organic Compounds on Activity of Steel in Acid Solution". J. Electrochem. Soc., 97, 2, 1950). 